\title{
Lavalle's Remains: The Political Uses of the Body in Exile and Return
}

Edward Blumenthal

Hispanic American Historical Review 97:3 (2017)

doi 10.1215/00182168-3933814 2017 by Duke University Press

Abstract This article analyzes through the prism of exile and return the journey of General Juan Lavalle's remains from the battlefield to Bolivia, Chile, and then Buenos Aires. After the death of Lavalle at the hands of Federalist militias in Jujuy province in 1841, his followers carried his bones and heart with them to Bolivia. His remains became a focal point of exile politics in Bolivia and Chile, where republican funerals were held in Lavalle's honor. The return of Lavalle's remains, sponsored by the Buenos Aires government and organized by émigrés in Chile, became part of the conflict between the province and the Argentine Confederation in the 1850s. Exile and return, embodied by the remains, were important yet conflictual experiences that legitimized the post-Rosas order. The role played by émigrés in the repatriation of Lavalle and the debates over his memory highlight the politics of transnational exile at the heart of the new republic's organization.

Much of the research for this article was made possible by a grant from the "Itinerarios singulares e identidades plurales" project, organized by CONICET (Argentina) and the Université Diderot Paris-Sorbonne-Cité (France). I am also grateful to the editors and reviewers of HAHR for their valuable comments.

Death at the hands of Federalist militias in 1841 was only the beginning of a long journey in exile for General Juan Lavalle. After Lavalle fell in Jujuy province during the Argentine civil wars pitting Federalists against centralist Unitarians, his soldiers removed the rotting flesh from his body and fled with his bones and heart into neighboring Bolivia. From there, his remains traveled to Chile in the following year, only to return to Buenos Aires in 1861, at a moment of intense struggle between the city and the other provinces of the Argentine Confederation. At each stop along the way, Argentine exile communities made use of Lavalle's remains in their political 
struggles, primarily through public funerals. ${ }^{1}$

Though their fight was first against Juan Manuel de Rosas, governor of Buenos Aires and de facto head of the Argentine Confederation between 1829 and 1852, after Rosas's fall these communities became embroiled in the internecine political struggles among the erstwhile antiRosas groups. Distrustful of the motivations of Justo Jose' de Urquiza - who was governor of Entre Ríos, head of the international military coalition that had ousted Rosas, and eventually president of the Argentine Confederation (1854-1860) - Buenos Aires seceded from the confederation in 1852, which led to a decade of separation and debate that often turned into warfare. ${ }^{2}$ The repatriation of Lavalle's body played an often-conflicting role in these struggles, symbolizing both Buenos Aires province's historical memory and the needs of organizing a nationality, as it was often called. The repatriation process stood in for exile and return while revealing the political fissures of the post-Rosas era.

The repatriation of Lavalle's body was part of a larger trend amid the exile and banishment of political leaders in the decades following independence. Leaders who died in exile were repatriated to their countries' capitals with the symbolic objective of unifying the body politic, exercises of republican pedagogy in which the deceased leaders incarnated republican values. Repatriation was a way to reconcile the wounds of war, among which exile and exclusion figured prominently, but it was also a political instrument that created a historical narrative aimed at unifying the nation and legitimizing leaders.

These republican funerals mobilized Christian and monarchical symbol- ism to consecrate republican heroes and found patriotic myths. The role of deceased leaders in painful historical events was often glossed over in order to transform them into unifying republican heroes. The ceremonies commemorated the republican experience, connecting past, present, and future to the body of the deceased leader. This was used by republican regimes to legitimize their rule, connecting the present to a shared memory of sacrifice and independence. Many of these republican leaders were exiles themselves, such as Bernardino Rivadavia, José de San Martın,

1 Very little work has been done on exile as such in the nineteenth century. One exception, from a political science perspective, is Sznajder and Roniger, Politics ofExile. See also the suggestive text Rojas, Las repu'blicas.

2 Adelman, Republic, 196-202; Scobie, La lucha. 
Martın Güemes, José Gervasio Artigas, Bernardo O’Higgins, or Agustın Gamarra. ${ }^{3}$ Napoleon's repatriation had taken place in 1840 and was widely covered in the press, setting perhaps the gold standard for state funerals.

This concern with the sacrality of the body as a symbol of political struggle is also related to the theme of violence to the body, often extreme, as a political and cultural practice. The mutilation of bodies was central to the practices of warfare both during and after the independence wars. An important goal of this symbolic terror was to either force submission or provoke exile. In the Río de la Plata, one common practice was degüello (decapitation) and the public display of the head on a pike, a form of humiliation after death. This indeed was what Lavalle's followers were trying to avoid when they fled to Bolivia with his body in 1841. From this first flight, his body was to his followers a symbol of death and exile rather than submission and humiliation. ${ }^{4}$

One important difference, though, between the experience of Lavalle's remains and the larger genre of republican funerals, many of which include a return from exile or a reincorporation of an excluded figure into the national pantheon of heroes, is the multiple displacements and conflicts endured by the remains of Lavalle, due to his martyrdom on the battlefield. As we will see, the decision to remove his body from Jujuy was made in order to prevent its desecration by Rosas and his allies. His body circulated among the Argentinean exile communities to create national cohesion from outside the future borders of Argentina. But his body's return was subject to sometimes conflicting uses by émigrés, the confederation, and Buenos Aires. This disputed process of repatriation makes the journey of Lavalle's remains ideal for studying the problems associated with not only the political symbolism of the body and violence but also the phenomenon of exile and return.

In this article, I will argue that the specific problems of constituting a unified republic in the Rio de la Plata-problems related not only to the divisions between Buenos Aires and the confederation but also to the fact that the new governing class had spent years, if not decades, in exile-are reflected in the conflicting interpretations of Lavalle's legacy and repatriation. The repatriation of Lavalle's remains both highlights and symbolizes these divisions and the

3 Caretta and Zacca, "Itinerarios"; McEvoy, Funerales republicanos.

4 On violence in the wars of independence, see Adelman, "Rites." On military practices and violence more broadly in the Río de la Plata, see Rabinovich, La société guerrière. For memory and the body, see Johnson, Death. 
problems of return. Return in this sense is return not from absence but rather from a concrete social experience of living abroad. While the literature on republican funerals often focuses on founding fathers, these leaders were frequently part of wider communities that straddled new national borders and often included political émigrés. These funerals were thus not simply cases of repatriation, as transnational political communities played an important role in them, even when the émigrés did not themselves return. So it was with Lavalle's eventual funeral. Sites of exile, inhabited by communities of émigré's, guarded Lavalle's body and played an important role in its return. This return was symbolic of not only the end of the Rosas-era waves of exile but also the new divisions that grew out of Rosas's fall, and the metanarrative of exile was used by different factions in political struggle. Lavalle's remains had different meanings for different actors. 


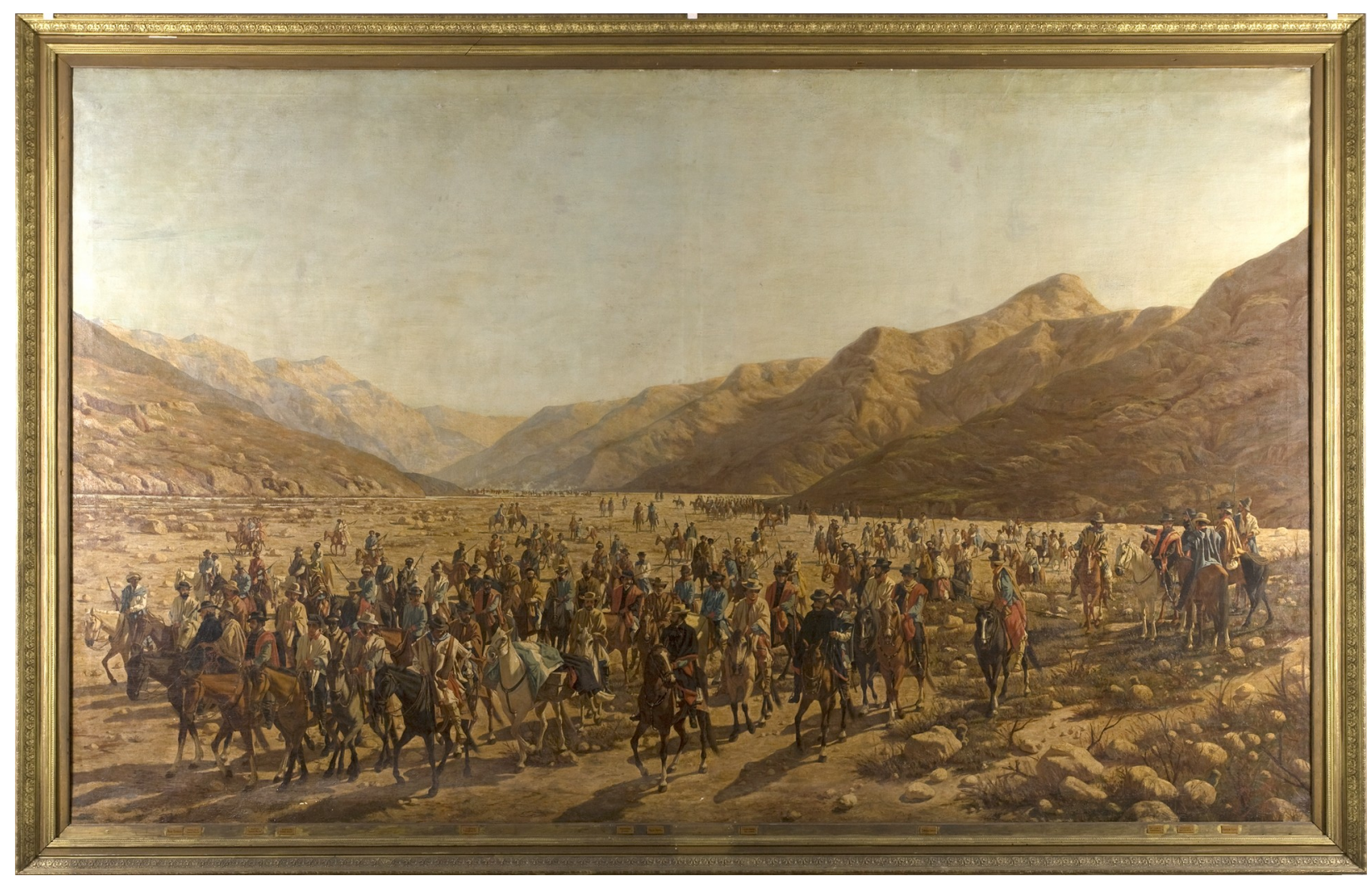

Figure 1. La conducción del cadáver de Lavalle en la Quebrada de Humahuaca, by Nicanor Blanes (1889). Courtesy of the Museo Histórico Nacional de Argentina.

This symbolism explains the use and reuse of this metanarrative, beginning with the members of the original expedition who removed Lavalle's body and continuing into the twentieth century. An 1889 painting by Nicanor Blanes shows the expedition's flight, identifiable individual officers, military heroes, heading into exile with Lavalle's body draped in the flag standing in for the unification of the republic (figure 1). ${ }^{5}$ The painting highlights the concern with the sacrality of the body as a symbol of political struggle, with the body representing the exile experience and the triumph of Buenos Aires in the context of the capital's federalization.

In Sobre héroes y tumbas (1961), Ernesto Sabato used the story of Lavalle's soldiers fleeing with

5 Rodriguez and Ruffo, "Paisaje." The caption accompanying the painting in the Museo Histórico Nacional de Argentina helpfully identifies the officers by name, as did La Nación (Buenos Aires), 13 June 1889: see Rodriguez and Ruffo, "Paisaje," 7. The painting was based on Pedro Lacasa's narrative, and Blanes donated it to the Buenos Aires legislature not long after the federalization of the capital in 1880, which finally resolved Buenos Aires city's position in the nation. 
his body so that their enemies "will never dishonor the general" as the backdrop for his characters' lives under the first era of Peronism and as a metaphor for the divisions in Argentina that led to civil war, death, and exile in the nineteenth and twentieth centuries. Lavalle's soldiers fled north as Sabato's main character fled south, to Patagonia. While the latter's exile may have been more existential than political, the recurrence of Lavalle's remains in this text as a visceral metaphor, with its "atrocious" smell and the tears of army officer Alejandro Danel as he "sinks his knife into the rotten flesh," suggests the power that the body has to represent themes not only of exile and division but also of reconciliation and union. ${ }^{6}$ The body has been used, in exile and return, to legitimize power as well as imagine alternatives from the moment of Lavalle to the present.

\section{Lavalle: Exile and Factionalism}

As an independence hero and military leader whose career spanned much of South America, Lavalle might appear an apt symbol of Argentinean unity. He began his military service shortly after the autonomist junta of 1810 and participated in the taking of Montevideo from the royalists and in the fighting against the Federal League of provinces in rebellion against centralist forces in Buenos Aires. He later joined the Argentinean-Chilean army that would liberate Chile from Spanish rule in 1817. Subsequently, he served under San Martın and Simón Bolivar in the independence wars for what would become the countries of Peru and Ecuador. ${ }^{7}$ Lavalle's military service traced the early history of post independence Rio de la Plata and much of South America.

The return of Lavalle to Buenos Aires province in 1824 coincided with the crystallization of Unitarianism, a political force he became closely associated with. The provincial government, under the leadership of Minister of Government Bernardino Rivadavia, implemented a series of reforms designed to create republican institutions, such as a provincial assembly, universal male suffrage, and an end to tithing. ${ }^{8}$ By 1825 , when Buenos Aires called for a congress to write a constitution and unify the provinces of the Rio de la Plata as a single nation, these reforms and

6 Sabato, Sobre héroes, 85.

7 The most recent biography of Lavalle is Pasquali, Juan Lavalle. The first was written by an officer who served under him: Lacasa, Vida militar. The available biographies of Lavalle remain hagiographic.

8 This was known as the "feliz experiencia" of 1820-1824. Gallo, Struggle. 
others, such as the land reform that led to an expansion of large-scale cattle raising in the south of the province, generated opposition to Rivadavia's faction. Associated with the centralist constitution of 1826, Rivadavia's followers became known as Unitarians. ${ }^{9}$

Upon returning to Buenos Aires, Lavalle joined the province's armed forces, soon to be nationalized and sent to war with Brazil. In order to prevail over the Federal League, the Buenos Aires government had acquiesced to a Portuguese takeover of Uruguay in 1817. The 1825 congress, which had included Uruguayan representatives and assumed that Uruguay would become part of the new United Provinces of the Rio de la Plata, also led to conflict with Brazil (which had gained independence in 1822). The new national government, after 1826 under the leadership of now-president Rivadavia, was soon sucked into a bloody and costly war that, coupled with internal opposition to the Unitarian constitution and centralized government, led to the breakup of the United Provinces of the Rio de la Plata into provinces now ruled independently for the second time in a decade. In 1828, new elections led to the victory of the opposition Federalist faction in Buenos Aires province and a new governor, Manuel Dorrego. In that year Dorrego signed the treaty with Brazil that ended the conflict, with both Buenos Aires and Brazil agreeing to recognize Uruguayan independence.

This was the scenario that Lavalle encountered upon his return from war with Brazil in 1828: a Federalist governor, suspicious of Unitarians as well as the military leaders associated with centralist projects going back to San Martın, and soldiers unhappy with the dissolution of the United Provinces of the Rio de la Plata and the treaty signed with Brazil. Lavalle organized a coup against Dorrego the same year, executing him and becoming governor in his place, which led to an uprising in the countryside south of Buenos Aires city and violence that quickly spun out of control. ${ }^{10}$ Dorrego's execution broke with a tacit intraelite policy that allowed for exile rather than death for defeated leaders. Exile often operated as an escape valve in such cases, granting well-placed members of the elite a somewhat graceful exit from the country and avoiding the passions and renewed violence that execution might stir up. ${ }^{11}$ Indeed, the execution of Dorrego did exactly this, as his reputation among the urban poor and the gauchos of the

9 Zubizarreta, Unitarios.

10 Fradkin, ;Fusilaron a Dorrego!

11 Sznajder and Roniger, Politics of Exile. Poorer dissidents were not always so lucky. 
countryside led to an uprising in the south of Buenos Aires and an invasion from neighboring provinces. Though Lavalle's forces resorted to violent repression, they could not put down the uprising, and he sought a negotiated solution that turned into a political defeat.

The immediate consequence was the ascension to power of Juan Manuel de Rosas as governor of Buenos Aires and de facto ruler of the Argentine Confederation, a loose grouping of provinces over which Rosas would consolidate power during the 1830s. His authoritarian, conservative rule, which lasted until 1852, resulted in waves of exile into neighboring countries, in particular Uruguay, Bolivia, Chile, and Brazil. Lavalle was part of the first wave; he settled in Uruguay, where he remained a prominent military figure, allying with Fructuoso Rivera against Rosas's ally Manuel Oribe and participating in several armed expeditions against the confederation.

The 1828 coup and Dorrego's execution remained stains on Lavalle's record, even for his exiled allies in the struggle against Rosas. Fellow Unitarians from the civil wars of the 1830 s, such as General José María Paz, called Dorrego's execution an "unjustifiable act” that allowed Rosas to justify his own "bloody atrocities." 12 General Gregorio Aráoz de la Madrid, while echoing this assessment, went further, calling Lavalle stubborn, arrogant, and unwilling to listen to his subordinates or peers. ${ }^{13}$ Though these comments in part reflect personal divisions among Unitarian generals, they echo the widespread assumption that Dorrego's execution was a major error, if not a crime, that unleashed the violence of the 1830s - and led to Rosas consolidating power.

Lavalle went on to lead an uprising against Rosas in 1839 from neighboring Montevideo. In the tense atmosphere leading up to this campaign, a key moment in the Rosas regime, attitudes toward political dissent hardened in Buenos Aires, generating new waves of exile, imprisonment, and political assassination. Lavalle's army brought together a wide range of anti-Rosas exiles, who did not always see eye to eye. These included not only Unitarians who had fled Rosas or his provincial allies in 1829 but also dissident Federalists and the young Romantic Generation of 1837, who had seen in Rosas a figure capable of undertaking national organization. When it became clear that Rosas had no intention of calling a constitutional convention and deeply

12 Paz, Memorias, 76-77.

13 La Madrid, Memorias, 389-92. 
mistrusted the Romantics' use of the press and public opinion, they too became subject to repression and fled into exile. ${ }^{14}$

Despite the backing of the French, who imposed a blockade on Buenos Aires, Lavalle decided not to take the city, and he retreated to the north, toward the province of Salta. In Salta, after his defeat at Quebracho Herrado and the flight of much of his army, Lavalle continued his retreat north with his reduced forces. He found death by happenstance on October 9, 1841, when a party of montoneros (gaucho guerrillas) fired on the house where he was staying in Jujuy, which they believed to belong to Unitarian sympathizers, and hit Lavalle in the neck, killing him. ${ }^{15}$ From there his body was spirited across the border to Bolivia by his loyalists, on their way to their own exile.

The decision not to attack Buenos Aires in 1839 was the subject of controversy among émigrés. Tomás de Iriarte, a Federalist who had fled to Montevideo after Dorrego's execution in 1828, returned when Rosas became governor in 1829 and then fled again in 1833, when Rosas assumed dictatorial powers. Though he joined Lavalle in 1839, he remained suspicious of the Unitarian general, and he complained of Lavalle's "contempt" for him. Interestingly, he attributed to the shadow of Dorrego's execution Lavalle's decision not to attack Buenos Aires and to instead fight Rosas's provincial allies. This decision was in Iriarte's view a product of Lavalle's fear of his own execution, "the punishment of his own crime."16

The young Romantics echoed these opinions. Domingo Faustino Sarmiento called Dorrego's execution a political error - again, because of the wave of violence that it provoked - while also criticizing Lavalle's disdain for gauchos. More generally, he criticized Unitarians in historicist terms for misunderstanding the origins of Rosas and his popularity, although he characterized the execution as a historical inevitability. ${ }^{17}$ Other Romantics critiqued Lavalle, and Unitarians more broadly, in generational terms. Esteban Echeverría famously drew a parallel between how Rosas spurned the Romantics' offer of alliance in the 1830s and Lavalle's supposed unwillingness to

14 The literature on the politics and legacy of this generation that shaped the exile experience, known as the Generation of 1837, is vast. See, for example, Katra, Argentine Generation; Myers, "La revolución."

15 A recent analysis of the campaign can be found in Gelman, Rosas. One of the first accounts was written in exile by an officer who had accompanied the body: Lacasa, Campaña.

16 Iriarte, Memorias, 143-44.

17 Sarmiento, Facundo, 106. 
listen to the Romantics' advice. Lavalle was a "sword without a head," unable to listen to his secretaries, Juan Bautista Alberdi and then Félix Frıas. ${ }^{18}$ Alberdi, while defending Lavalle generally, posed the strategic argument of whether Lavalle should have attacked Buenos Aires immediately in 1839, as opposed to amassing support in the littoral provinces. While referring to Lavalle as a "leader of the noble ranks of the Unitarian party" whose "sincerity" and "patriotism" were beyond question, Alberdi late in life complained about his lack of influence with Lavalle, who along with the Unitarian generals was old and out of touch with the social realities of Buenos Aires and the "youth revolution."

All these opinions were written retrospectively, with an eye toward justifying their authors' actions. Yet they reflect a certain historical memory of the events themselves and the way that anti-Rosas émigrés sought to portray themselves before and after the Battle of Caseros in 1852, when Rosas fell to an alliance of dissident provinces allied with Brazil and Montevideo under the leadership of Urquiza. More than a symbol of unity even among anti-Rosas émigrés, Lavalle represented the spiral of violence unleashed by Dorrego's execution and the strategic and factional differences that divided the émigrés. Yet despite their differences, these factions were nonetheless united in rejection of Rosas and a shared experience of exile, repression, and violence during Lavalle's campaign of 1839-1841, during the 1840s abroad, and amid repatriation in the $1850 \mathrm{~s}$. The memory of exile comes out clearly in a statement from one of the constitutional clubs that sprang up on the Pacific coast to participate in the constitutional organization of the republic after Rosas's fall in 1852: “The Argentineans residing in Chile are neither porteños nor provincial, but rather Argentineans from all parts of the Republic, men cast out in different eras and circumstances from the heart of the country and who have fought, succumbed, or persevered in the hope of seeing the goal of organizing the country realized, to which so much blood, tears, time, and fortunes have been sacrificed." ${ }^{20}$ It was Lavalle's standing as a founding father-not just of Argentina, but of the larger Spanish American independence movements - and the memory of exile that allowed Lavalle's repatriation to be a symbol of Argentinean unity, albeit a problematic one that would provoke dissent during the conflict

18 Halperín Donghi, “Una nación,” xvii.

19 Alberdi, Memorias, 445-46.

20 "De los argentinos residentes en Santiago de Chile ...," Santiago, 1852, in Sarmiento, Las ciento, 83. 
between Buenos Aires and the confederation.

\section{Death and Exile}

The mythologizing of Lavalle's posthumous travels began with the story of the border crossing. Alejandro Danel, an officer in Lavalle's army, narrated the events after Lavalle's October 1841 death. ${ }^{21}$ According to Danel, the corpse began to decompose and was giving off an odor. Some members of the party offered to cut off its head in order to carry it to Bolivia and to bury the body on the spot in Jujuy. In light of Danel's opposition to this measure, the commanding officer, Juan Esteban Pedernera, proposed that Danel separate the corpse's flesh from the bone to prevent the Federalists from putting the head on a pike. ${ }^{22}$ Using only his "humble knife," Danel did what he had to, and Lavalle's "remains continued their funeral march, emigrating from the patria that he had served in so many battles, spilling his blood from Ecuador to the memorable elds of Ituzaingó." ${ }^{23}$ Lavalle's republican, independence credentials figure prominently in Danel's telling. Danel's actions were a cruder alternative to the embalming techniques of this era, a practice at the intersection of public hygiene and the secular, republican cult of the hero that was used in Napoleon's funeral and also in San Martın's repatriation in 1880. Not having access to these more sophisticated techniques in the Jujuy desert, Danel needed to proceed in a more gaucho fashion. It also greatly facilitated subsequent exhumations and travel. ${ }^{24}$

For Pedro Lacasa, another member of the party that escaped into Bolivia with Lavalle's body, their rescue of the general's remains was a "unique example in the annals of war." ${ }^{25}$ Lacasa argued that unlike past armies in retreat, whose soldiers rescued their officers or bravely protected bodies fallen in combat, only the soldiers of the "Argentine Republic" had fought daily after their defeat to take their leader's remains into exile and protect them from profanation. Lacasa wrote this during the repatriation of Lavalle's remains 15 years later, in the 1850 s, when they had already acquired an important symbolic dimension related to exile, civil war, and the

21 Danel, a French officer under Napoleon, was recruited by Rivadavia to fight for the independence of the Rio de la Plata. After arriving in Buenos Aires in 1817, he fought against the Federalists, first serving in 1822 under then-colonel Lavalle in Brazil. Danel, "Auto-biografia."

22 Danel refers to the "cruel profanation of tyrants." Ibid., 60.

23 Ibid., Danel notes that he had been expected to follow his father's example and become a doctor.

24 Podgorny, "Las momias." The sources that mention Lavalle's remains often refer to them as "ashes" (cenizas), which, rather than implying cremation, was a synonym for remains.

25 Lacasa, Vida militar, 108. 
difficulties of organizing the republic.

Understanding the context of exile is central to understanding how Lavalle's remains immediately took on a symbolic role, unifying the émigrés in Bolivia and keeping them focused on the struggle against Rosas. This was no doubt useful for a group diverse in terms of both faction and provincial origin, with the Argentine Republic yet to be constituted. Lavalle's body kept the émigrés together, and a series of exile associations sprang up in Bolivia to participate in Lavalle's funeral and continue the political struggle against Rosas. As a figure in the broader Spanish American independence revolution, Lavalle allowed the exiles to call on the solidarity of their Bolivian hosts and to blur the differences between Buenos Aires and the other provinces of the Argentine Confederation.

Upon arriving in Bolivia in 1841, the émigrés were welcomed by the prefect of Potos1, and Lavalle's remains were deposited in the cathedral. ${ }^{26}$ One of the exiles' first actions was to set up a commission to organize Lavalle's funeral. A meeting of "all the émigrés" in the city of Potosí elected an executive commission to coordinate a subscription to pay for the ceremony. ${ }^{27}$ The commission emphasized that the subscription was to be paid "exclusively by Argentineans" and that the funeral called for the "formality and circumspection that such an act requires and that is the duty of said émigrés." The goal seems to have been to channel the émigrés' political loyalties, what the commission called "classic proof of loyalty [adhesión] to the general's person." Loyalty was as much personal loyalty to the general as national loyalty to Argentina; yet the exile leaders themselves aimed to generate national sentiment among émigrés. ${ }^{28}$

The commission sought to create a state funeral, albeit in the absence of an Argentine state, both to legitimize their struggle and politicize the émigré population. The commission contacted émigrés in other Bolivian cities for this same purpose, including Lavalle's former secretary Félix Frias and the independence-era general Rudecindo Alvarado in Sucre. ${ }^{29}$ Frías's reply shows that

26 Ibid., 109.

27 "Acta de la Comisión de Potos1," 5 Feb. 1842, Archivo General de la Nación, Buenos Aires (hereafter cited as AGN), Colección Biblioteca Nacional, leg. 686, no. 11.195. Two hundred three émigrés elected a five-person commission, made up of members of Lavalle's army, to coordinate the funeral.

28 Ibid.

29 Potosí commission to R. Alvarado, Potos1, 13 Feb. 1842, AGN, Colección Biblioteca Nacional, leg. 687, no. 11.355 . 
the commission was able to raise money. ${ }^{30}$ The commission also hoped that a state funeral would attract Bolivians and foreign dignitaries. The funeral was organized in coordination with the French consul in Sucre, Andres Villamus. ${ }^{31}$ The official representatives from Bolivia and abroad provided legitimacy to the émigrés and their struggle.

In a letter to Lavalle's widow, Dolores Correa de Lavalle, the commission focused on some of the same themes, informing her of the success of their efforts and the importance of the funeral. In addition to the French backing, they noted the attendance of the "most distinguished Bolivians" (primeras notabilidades del país), that the funeral took place in Potos1 city's principal cathedral, and that not even one émigré missed the event, despite their "poor clothing." 32 The search for foreign - in particular European - dignitaries, the massive turnout, and the appropriate setting could not hide the poverty of the funeral. This was, perhaps, part of the point. In the contrast between the émigrés' poverty and their a affirmations of the nobility of Lavalle's struggle against Rosas, they emphasized their identity as exiles from a nonexistent country.

This can be seen in the funeral speech given by Pedro Lacasa. Lacasa noted the presence of "many Bolivian patriots," who "understood that the hero . . . was not only a soldier of the Argentine Republic and that his glory is property of the American Continent." He then called on the citizens of Potosı to guard Lavalle's remains until they could safely be returned to their home: "Potosinos! This sacred deposit will remain with you: preserve it. . . The great pueblo of Buenos Aires will thank you for having preserved in your bosom the first defender of its civic liberty." 33 By linking the exiles' struggle to the wars of independence, Lacasa sought political legitimacy and solidarity, in addition to linking the fate of Buenos Aires to that of Potosi city.

Many of the soldiers present had fought in these wars, whether in Upper Peru (considered by Buenos Aires to be under its jurisdiction until it recognized Bolivia's independence in 1825), the

30 Félix Frias to Potosı commission, Sucre, 10 Feb. 1842, in Revista de la Biblioteca Nacional (hereafter cited as $R B N)$ 24, no. 58 (1951): 420-21.

31 "Acta de la Comisión de Potosí," 5 Feb. 1842, AGN, Colección Biblioteca Nacional, leg. 686, no. 11.195. The commission later thanked the French consul in Montevideo, Henri Buchet-Martigny, for his part in paying for the funeral. Potosí commission to Henri Buchet-Martigny, 27 Mar. 1842, AGN, Colección Biblioteca Nacional, leg. 689, no 11.768 .

32 Potosı commission to Dolores Correa de Lavalle, Potosı, 23 Mar. 1841, in RBN 25, no. 59 (1958): 46-47. Frias himself was not able to attend the funeral, because he had neither "a horse nor the resources." Félix Frias to Potosí commission, Chuquisaca, 9 Feb. 1842, in RBN 24, no. 58 (1951): 418-19.

33 Lacasa, Vida militar, 110. 
Rio de la Plata, or the Andes. These cross-border ties can be seen in the presence of at least two commission members born in Upper Peru, despite the insistence that subscriptions be made "exclusively by Argentineans." ${ }^{34}$ The identification of these two members with Argentina was based on military loyalty and ideology born in the independence wars, and their participation in the funeral commission was a reminder of this bond. These independence-era links no doubt provided the émigrés with an additional degree of legitimacy in Bolivian society.

Implicit in Lacasa's call was the question of the émigrés themselves. In Lacasa's funeral speech, Lavalle's body symbolized connections between American peoples that could be used to generate sympathy and solidarity. By keeping the body in their city's cathedral until it could be buried with due honors in Buenos Aires, the citizens of Potosí were implicitly agreeing to take in the exiles. The body in this sense represented a pact by which the people of Bolivia would host the émigrés until political conditions changed and Rosas could be overthrown. It symbolized the political values represented by Lavalle, the attachment of the émigrés to Buenos Aires, and their connections to their host country. Indeed, during the 1840s the Argentine émigrés played an important role in Bolivian journalism and education, as well as serving in the military under President José Ballivián. ${ }^{35}$

Lavalle's Bolivian funeral and the émigrés' integration into Bolivian public life coincided with Ballivián's rise to power - and a struggle over the body of his deceased rival, Agustın Gamarra. In 1841 Ballivián returned from exile in Peru, assumed the presidency, and then defeated an invasion from Peru headed by Gamarra via a cross-border movement not unlike that of the Argentinean émigrés. The treaty signed by Bolivia and Peru in 1842 contained provisions for the return of Gamarra's body to Peru. Nevertheless, its repatriation would have to wait until 1848 and a new president. This eventual return started a revision of Gamarra's memory meant to end the anarchy, civil war, and transnational adventures in Bolivia-a revision similar to the one

34 Casimiro Rodríguez, a member of the Potosí commission, and Juan Estanislao de Elías, a signatory of the Sucre subscription, were independence-era officers who had fought under Lavalle in the 1839-1841 campaign. Elías was the confederation's chargeé d'affaires in his native city of Sucre after Rosas's fall.

35 Their integration into Bolivian society was facilitated by a political alliance with Ballivián, whose brother-in-law was the Uruguay-born anti-Rosas officer Wenceslao Paunero. The names that appear on the lists of émigrés make it clear that many were from border regions with long-standing ties to Upper Peru. This fluid, nonexclusive nationality has been analyzed in Sobrevilla Perea, Caudillo. 
being spearheaded by Lavalle's followers. ${ }^{36}$ Underscoring these connections to the Peru-Bolivia border region is the fact that a squadron of porteños that had accompanied Lavalle's remains to Bolivia was sent north and defected to the Peruvians, while Pedernera and his soldiers were incorporated into the Bolivian army and fought against Gamarra in $1841 .{ }^{37}$

After the funeral the commission's actions continued, with the formation of Argentine commissions in various Bolivian cities on the model of the ones existing in Montevideo, Uruguay, and Santiago. These commissions negotiated with host country governments and European powers while funneling arms and supplies to insurgent armies in the field. They also tried to protect émigrés, particularly the best placed socially, from the vicissitudes of exile. The funeral commissions in Potosí and Sucre merged into the new political commissions founded a few months later, which often had the same leaders and many of the same members. The Argentine commission in Bolivia was first called the "commission to congratulate President Ballivián," again highlighting the importance of local politics. ${ }^{38}$ Interestingly, the funeral commissions attracted many more voters than the subsequent Argentine commissions, indicating perhaps that independence-era Americanism and Lavalle's personal attraction were still more powerful forces than an incipient Argentine nationalism among émigrés.

On February 5, 1842, Lavalle's ashes were sent to Valparaíso, Chile, apparently at the request of his widow, who was exiled in Chile with their son, also named Juan Lavalle. The remains were then buried in the local cemetery. ${ }^{39}$ Although the reason for the move is not entirely clear, it reflects a general movement of exiles toward Chile amid the siege of Montevideo by Rosas's ally Oribe, which endangered one of the key émigré refuges. The fall of Bolivian president Ballivián in 1847 only contributed to this movement.

Although there is little material on the use of Lavalle's remains among the eémigrés in Chile between 1842 and the establishment of a repatriation commission for the remains in 1858, one hint comes from an article published by Sarmiento decades later concerning Lavalle's sword.

36 Sobrevilla Perea, "La repatriación." This reconciliation came in the aftermath of the breakup of the Peru-Bolivia Confederation in 1839.

37 Félix Frias to J. M. Gutié rrez, Chuquisaca, 1 May 1843, in $R B N$ 25, no. 59 (1951): 70; Félix Frías to Miguel Piñero, Chuquisaca, 7 Jan. 1843, AGN, Colección Biblioteca Nacional, leg. 679, no. 9.915.

38 Acta, Potosí, 27 June 1842, AGN, Colección Biblioteca Nacional, leg. 685, no. 10.904.

39 Pasquali, Juan Lavalle, 392. 
Brought to Chile in 1843 by Frías, it was displayed prominently on the estate of Emilia Herrera de Toro, a Chilean who had married the émigré Mariano Sarratea. Sarmiento used the anecdote of the sword, on the occasion of its being sent to Buenos Aires, to highlight Herrera de Toro's estate as a place of sociability for the émigrés and their integration into Chilean society more generally. $^{40}$

\section{The Repatriation Commission}

Chile was a haven not only for Lavalle's remains but also for the Argentine émigrés over the following years. Some stayed in Chile well after Rosas's fall at the Battle of Caseros in 1852, when many returned to the Río de la Plata to participate in the constitutional process that founded the Argentine Republic. The divisions between Buenos Aires and the rest of the provinces persisted, however. Following fights over its role in the new constitutional structure and control of the revenue-producing customs office, Buenos Aires seceded from the confederation, producing conflict that would last for a decade. Two parties, the Argentine Confederation and the province of Buenos Aires, both claimed to represent the nation. Both approved constitutions, set up state institutions, and sought diplomatic recognition abroad. Divisions abroad mirrored those in the Río de la Plata, as former exiles found themselves on opposing sides of the conflict, organized into competing constitutional clubs. ${ }^{41}$

Lavalle's remains became part of that struggle. In 1858, the Buenos Aires assembly passed a resolution authorizing the "executive power" to move the remains to the province and appropriated the necessary funds. ${ }^{42}$ This was part of a broader effort by the provincial government to consolidate its political legitimacy in the conflict with the confederation. During this period, other efforts were made to crystallize a porteño memory by invoking republican values, in particular by establishing a pantheon of figures associated with Buenos Aires city. ${ }^{43}$

40 Domingo Faustino Sarmiento, “La espada de Lavalle,” El Nacional (Buenos Aires), 18 Oct. 1882, in Sarmiento, Páginas, 78-80. The sword was returned by Carlos Lamarca, son of the confederation's diplomatic o cer in Chile. This absence of source material is a noteworthy indication of the precariousness of the exile experience itself and the cost that mobility can have on the conservation of sources.

41 Bragoni, "La utopia."

42 Buenos Aires provincial law, Buenos Aires, 8 June 1858, in Lacasa, Vida militar, 112-13.

43 González Bernaldo de Quiro's, Civilité, 310-16. Pilar González Bernaldo de Quirós highlights how in a second phase that lasted from 1860 to 1862, urban planning policy began to give Buenos Aires city the appearance of a future national capital, explicitly invoking the Argentine nation and not only the memory of the province. Ibid., 
Notably, in 1857 Bernardino Rivadavia's remains were returned to the city in a public ceremony that highlighted his role as a liberal reformer in the province and tied the provincial government to his legacy. This had the benefit of both emphasizing his role in establishing republican institutions in the province and effacing his more controversial role as president of the United Provinces of the Rio de la Plata. ${ }^{44}$ Other figures were also mobilized, such as San Martın, in whose honor an equestrian monument was erected in 1862, this time linking him to the nation, not Buenos Aires city. San Martín's remains would be repatriated in 1880, in a context of political tension created by the city's federalization.

Lavalle as a symbol was more ambiguous, a porteño associated with both Buenos Aires city and the Spanish American struggle for independence, but his repatriation began as a symbol of the former. A similar evolution of Lavalle's historical memory was also occurring, and the repatriation of Lavalle's remains had been the subject of debate in Buenos Aires for some time. Lacasa's biography of Lavalle appeared, as part of the Galería de Celebridades Argentinas put together by Bartolomé Mitre, the same year that the provincial assembly approved his repatriation, and in the introduction Lacasa again underscored Lavalle's role in the independence movements across the continent, invoking San Martín's and Bolívar's praise of the "hero" as well as his taking up of arms against the "bloody existence of the executioner of the Río de la Plata," Rosas. ${ }^{45}$ The biography's conclusion explicitly evoked repatriation and included an appendix with the repatriation motions approved by the Buenos Aires assembly. Lacasa was not alone. A newspaper had been founded in Buenos Aires city in 1857 to call for the repatriation of Lavalle's remains. Titled La Espada de Lavalle, it was edited by "various youth" who often signed articles as "the Unitarian," and its masthead included a citation from Lacasa's 1841 Potosí funeral speech, which had emphasized the plight of Buenos Aires under Rosas. ${ }^{46}$ The regional context for repatriation was addressed explicitly, presenting the return of Rivadavia's remains as

316-22. As we will see, the repatriation of Lavalle's remains overlaps these two periods and is part of this change.

44 Gallo and Socias, "La repatriación." The first move to repatriate Rivadavia came from the Argentine Confederation. Salvador Maria del Carril, vice president of the confederation between 1854 and 1860 and one of the advisers behind Lavalle's decision to execute Dorrego, proposed the repatriation at a banquet in 1854 and received Urquiza's approval. Urquiza himself was allied with Lavalle in 1830 and 1831. This again demonstrates the limited value of the Unitarian label in predicting the alliances of the $1850 \mathrm{~s}$.

45 Lacasa, Vida militar, 5. Lacasa was also one of the few to defend Lavalle's execution of Dorrego, though this does not appear prominently in the vision of Lavalle that he promoted.

46 I thank Ignacio Zubizarreta for bringing this publication to my attention and facilitating access to it. 
a natural antecedent and also mentioning the remains of Bolívar (returned in 1842) and O’Higgins. ${ }^{47}$

This struggle between Buenos Aires and the Argentine Confederation was mediated by the e émigrés themselves. Many had remained abroad, having integrated into their host countries as merchants or in other professions, particularly in the first few years after Caseros. This large group of Argentines in Chile would contribute through the repatriation of Lavalle's remains to Buenos Aires's efforts to legitimize its position vis-à-vis the confederation and to achieve reunification on favorable terms. Because Lavalle was a hero of both the independence wars and the fight against Rosas, and because his body had resided abroad with the exile communities, the repatriation ceremonies offered an opportunity to mobilize memory in order to reinforce an antiRosas identity in both Buenos Aires province and Chile's émigré community. Lavalle's symbolic return to Buenos Aires would reaffirm the links between the former exiles and the city while reappropriating the fight against Rosas for the government of Buenos Aires against the confederation. The exile experience was itself an important part of this legitimacy, both abroad and in post-Rosas Rio de la Plata.

Debate over Lavalle's memory and its connection to the present continued in 1858 and 1859, in the run-up to war between the confederation and Buenos Aires. In a long-running polemic with La Reforma Pacifica - a Buenos Aires newspaper run by Nicola's Calvo sympathetic to the confederation - over the memory of Lavalle and of Unitarianism more broadly, La Espada de Lavalle portrayed this conflict as a continuation of that between Unitarians and Federalists. While La Reforma Pacıfica insisted that the terms Federalist and Unitarian were anachronistic, La Espada de Lavalle rendered Urquiza as Rosas's heir and justified Dorrego's execution as an act of "political abnegation." 48 On the other hand, Bartolomé Mitre, a minister in the Buenos Aires government who would later become governor of the province (1860-1862) and first president of the united Argentine Republic (1862-1868), was depicted as Lavalle's heir in the march to war with the confederation in the winter of 1859. The "young Unitarians" presented

47 "Venida de los restos de Lavalle," La Espada de Lavalle (Buenos Aires), 17 Dec. 1857, p. 4. The reference to O'Higgins is apparently to the 1844 law calling for his repatriation, given that his remains would not be repatriated until 1869. McEvoy, "El regreso."

48 "Unitarios y Federales," La Espada de Lavalle (Buenos Aires), 27 Dec. 1857, p. 1; "Los hombres del partido Unitario," La Espada de Lavalle (Buenos Aires), 27 Dec. 1857, p. 2. 
Alberdi and Gutiérrez as "traitors" to the cause for backing Urquiza. ${ }^{49}$ Calvo's paper accused $L a$ Espada de Lavalle of using the violent tactics of Rosas, which highlights how the ex-governor had become an insult to be bandied at one's adversaries. In short, the divisions of the 1850 s were interpreted in the light of the Unitarian-Federalist divisions of 20 years previous. ${ }^{50}$

A few months after the initial resolution to return Lavalle's remains, the provincial assembly passed another resolution naming a commission to carry out the transfer comprised of the exiles General Juan Gregorio de Las Heras, Dr. Gabriel Ocampo, and Mariano Sarratea, with Las Heras as president. ${ }^{51}$ Mitre, who had spent many years in exile in Montevideo, Chile, Bolivia, and Peru, was apparently the impetus behind the resolution. He sent copies of the assembly's resolutions with instructions for the commission to Las Heras and Ocampo, informing them of the decision to return "the immortal remains of the illustrious Argentinean to the bosom of the patria" and emphasizing the "honorific" nature of the nomination. ${ }^{52}$ In a letter to Lavalle's widow, Mitre claimed that the general's name had "never been erased from Argentineans' memory" and held out the prospect of the appreciation of the "people of Buenos Aires when [the remains] enter in triumph through the streets of the city of his birth, between the funerary pomp and the benedictions of four generations." 53 The tension between Lavalle's symbolic role as father of the

49 “Los tránsfugas,” La Espada de Lavalle (Buenos Aires), 7 July 1859, p. 1; “Derrámese sangre,” La Espada de Lavalle (Buenos Aires), 7 July 1859, p. 3. La Espada de Lavalle was not an official newspaper, and during the march to war one of its editors was exiled by the Adolfo Alsina government of Buenos Aires for being too bellicose. "Destierro de los amigos de causa," La Espada de Lavalle (Buenos Aires), 18 Sept. 1859, p. 4. The paper seems to have closed after Mitre's defeat at Cepeda in 1859.

50 The use of Unitarian to describe Buenos Aires's position is somewhat misleading, as those involved in the conflicts of the 1850s cannot be neatly divided into Unitarians and Federalists, even while those labels were used at that time - and subsequently - to explain the conflicts between the province and the confederation. The former exiles were split between those who defended the confederation and those who remained loyal to Buenos Aires, but these divisions did not necessarily follow previous factional lines. The fight over the terms should rather be understood as part of a debate over the historical memory of Lavalle and Unitarianism that was politically salient in the 1850s, and the use of the word Unitarianism as a reflection of La Espada de Lavalle's lack of influence. Myers, "La revolución"; Zubizarreta, Unitarios.

51 “Departamento de gobierno," Buenos Aires, 30 Sept. 1858, in Lacasa, Vida militar, 113. Interestingly, while La Espada de Lavalle celebrated the commission's nomination, they held that it should have been accompanied by a Buenos Aires-centered commission. "Los restos del inmortal Lavalle," La Espada de Lavalle (Buenos Aires), 15 Aug. 1858.

52 Bartolomé Mitre to Juan Gregorio de Las Heras, Buenos Aires, 30 Sept. 1858, Archivo Central Andrés Bello, Santiago, Colección Manuscritos (hereafter cited as ACAB, CM), AH1604 1. The letter to Ocampo uses much of the same language and refers to the return of the "precious relics" to the "pueblo bonaerense." Bartolomé Mitre to Gabriel Ocampo, Buenos Aires, 30 Sept. 1858, ACAB, CM, AH1605 1. The Archivo Central Andrés Bello of the University of Chile houses the correspondence of Gabriel Ocampo and most of the exchanges between the commission and the government of Buenos Aires.

53 Bartolome' Mitre to Dolores Correa de Lavalle, Buenos Aires, 30 Sept. 1858, in Lacasa, Vida militar, $221-22$. 
city and the nation was complicated by exile: Would he be returning to the city, or to the nation?

Lavalle, hero of both the independence fight and the struggle against Rosas, was well positioned to mobilize public memory and reinforce an anti- Rosas political identity shared by both the provincial government and the former exiles still abroad (as well as those residing in the Argentine Confederation, with its capital in Paraná). It helped that he was both a porteño and part of the larger struggle for independence in America, thus mirroring the blurred borders of the future Argentine Republic. Repatriating Lavalle's body allowed the Buenos Aires government to reaffirm ties with the émigré community and to appropriate the struggle against Rosas for legitimacy against the confederation.

Ocampo and the other members of the repatriation commission appear to have been carefully chosen for their position in Chile. They were all well-known members of Chile's Argentinean émigré community, participants in exile associations and well connected in Chilean society. ${ }^{54}$ Las Heras, by virtue of his role in the wars of independence, held a Chilean military commission and had lived in the country since 1826 , but he had recently negotiated his reincorporation into the Buenos Aires army. Éminence grise of the exile struggle, Las Heras was also of the same generation as Lavalle and symbolically united the neighboring countries. Sarratea was a merchant living in Valparaíso, married into a prominent Chilean family. Ocampo, a lawyer with long-standing roots in Chile dating back to the 1820s, had participated in the commission that revised Andrés Bello's civil code and would later author Chile's commercial code. He later became dean of the School of Law and Political Science at the University of Chile (in 1869) and a member of the Supreme Court (in 1877). ${ }^{55}$ On the repatriation commission, Ocampo would lead the negotiations while Sarratea would organize the repatriation itself.

None returned to Argentina, but they all maintained political and social ties with the country, as exemplified by their participation in the commission. This indicates that citizenship was not seen

54 Las Heras and Ocampo had both been members of Santiago's Argentine commission in the 1840s, and all three repatriation commission members had been part of the Argentine constitutional club founded by Domingo Faustino Sarmiento in 1852- 1853, which was loyal to Buenos Aires.

55 Ocampo had recently received Chilean citizenship by a special act of the Chilean congress, as had other foreignborn luminaries before him, such as Andrés Bello and Ignacio Domeyko. Jerónimo Urmeneta to Gabriel Ocampo, 11 Aug. 1858, ACAB, CM, AH1566; Miguel Luis Amunátegui Aldunate, "Copia del decreto que nombra a Gabriel Ocampo como miembro de la Corte Suprema de Justicia,” 1877, ACAB, CM, AH1572 1; Prado O., "Reflexiones." 
as exclusive, even at this late date, and highlights the importance of transnational political ties at a founding moment for the Argentine Republic. Though Ocampo had become Chilean the year before, this did not prevent him from taking on a quasi-diplomatic role on behalf of a foreign government eager to receive Chilean recognition. This was not just a vague cultural identification with his country of origin but rather the explicit backing of a breakaway province by a recognized neighboring country.

Ocampo's response to the commission shows that he undertook his role as a patriotic duty, despite the physical and political distance caused by exile. He declared how "I have received as a singular honor the task of contributing, even if weakly, to fulfilling the duty of the noble and enlightened pueblo bonaerense." ${ }^{.56}$ This illustrates the importance to the Buenos Aires government of mobilizing the e'migre's in Chile, both in the immediate task of returning Lavalle's remains and to secure their support as porten os in the con ict with the confederation, but it leaves open the question of how Ocampo and the other e'migre's would bene $t$, integrated as they were into Chilean society. Ocampo hinted at his own motivations in a letter to Correa de Lavalle, in which he alluded to previous oral understandings and asked for written confirmation of her objections to the repatriation in order to protect his reputation with the Buenos Aires government. ${ }^{57} \mathrm{He}$ seems to have sought to preserve political relations with the Buenos Aires government without necessarily planning to leave Chile. Repatriating Lavalle's remains consolidated relations between the future national capital and certain members of the émigré community in a way that was potentially beneficial to both parties. Ocampo's fear of how failure would a ect his reputation in Buenos Aires illustrates this.

The first attempt to repatriate Lavalle's remains in 1858 and 1859 nevertheless came at an inopportune time. By the southern winter of 1859 , when the commission was in discussions with Lavalle's widow, events in the Río de la Plata were edging toward war, with an intransigent government at the helm in Buenos Aires and the confederation continuing to suffer economically from the province's monopoly control of international customs revenue. Correa de Lavalle was reluctant to allow the repatriation of her husband's remains because of this political situation.

56 Gabriel Ocampo to Bartolomé Mitre, Santiago, 1 Jan. 1859, ACAB, CM, AH1606 The letters signed by Ocampo are drafts. They can also be found in General Lavalle.

57 Gabriel Ocampo to Dolores Correa de Lavalle, Santiago, 11 July 1860, ACAB, CM, AH1611 1. 
"Newspapers and private correspondence" informed her that Buenos Aires was in a state of war with the confederation, which would consume the government's "time and resources." The funeral ceremonies would, in her view, "distract" the government from more important duties, and the money would be better spent in the city's defense, in view of the "pursuit of greater goals that arise from the vital question that is being debated on the banks of the Plata River." Though "anxious to contribute to the fulfillment of the generous vows expressed by the Government and people of Buenos Aires in favor of the memory of my unfortunate husband," she also asked if it were not better to "await a more propitious era." 58

It is not clear whether Correa de Lavalle was hoping for the repatriation to occur at a moment of greater unity or if she was more concerned about her son making the trip around Cape Horn in a cargo boat in the middle of winter and then landing in a war zone. It is, nonetheless, clear that she had a voice in her husband's repatriation, regardless of what politicians in Buenos Aires and notables in Chile had to say. Thus, the repatriation of Lavalle had to wait, and it would depend on some sort of resolution of the conflict. Ocampo relayed this information to Buenos Aires and recommended "suspending our efforts" until the "political horizon of the province of Buenos Aires" was more favorable. ${ }^{59}$

\section{The Ceremony in Chile}

The defeat of Mitre's forces at Cepeda in October 1859 resulted in the naming of a constitutional convention in 1860, charged with amending the confederation's 1853 constitution according to compromise terms acceptable to both Buenos Aires and Paraná, and led to the province's eventual incorporation into the confederation. Mitre was nonetheless elected governor of Buenos Aires in 1860. This signaled the beginning of the end of the division as well as Buenos Aires's incorporation into a unified Argentine nation.

In Chile, it also signaled the renewed possibility of repatriating Lavalle's remains, and Correa de Lavalle was more amenable to the commission's plans the following year. At this point, the

58 Dolores Correa de Lavalle to Juan Gregorio de Las Heras, Santiago, 5 July 1859, ACAB, CM, AH1613. She also held that the boat hired by Sarratea in Valparaíso was not suitable for carrying passengers around Cape Horn in the middle of winter.

59 Gabriel Ocampo to minister of government, Santiago, 21 July 1859, ACAB, CM, AH1610 1. 
discussions between Ocampo and Correa de Lavalle shifted gears and began to focus on a trip that would cross the Andes and the interior provinces of the confederation on its way to Buenos Aires, instead of making the long voyage by sea around Cape Horn. A land trip across the mountains would allow the procession to pass through several Argentinean provinces instead of heading directly to Buenos Aires, thus presenting the repatriation of Lavalle's remains as a symbol of a united Argentina rather than the affair solely of the future capital city. The passage through the Andes would also follow in reverse the steps of the campaign to liberate Chile in $1817 .{ }^{60}$

The repatriation of Lavalle's remains would occur in this context of reconciliation and national unification, albeit not without tension: the underlying issues in the conflict between Buenos Aires and the confederation had not been resolved and would not be until the federalization of the capital 20 years later. The ceremony itself would signal national unity while reflecting these tensions. But it would also show how Argentineans outside the confederation's borders were determined to have a voice in the constitutional process at the foundation of the republic. Unity also meant return from exile.

The unification of Argentina continued to intrude on the commission's plans when organizing for the move picked up speed in the southern spring of 1860. The changing political context is reflected in Sarratea's notes to Ocampo on the efforts to coordinate the move. He emphasized that the central issue in the repatriation was ending the exile of Lavalle's remains, only now possible thanks to the unification of the nation:

Now that the unfortunate division between the pueblos of our patria has happily ended, though it still existed when those [i.e., the commission's] instructions were given, and now that we are united in one nation, that has its representatives here [in Chile]; I take the liberty of pointing out to you, the commission, that they be especially invited by the commission, in order to solemnize with their presence, the act of exhuming the remains of the illustrious compatriot who, after so many years, is going to rest in the land of the

60 Dolores Correa de Lavalle to Gabriel Ocampo, Santiago, n.d., ACAB, CM, AH1614 1. See also Ocampo's message to Buenos Aires, 27 July 1860, ACAB, CM, AH1612 1. 
patria. $^{61}$

As we have seen, by repatriating Lavalle's remains the commission was helping to legitimize Buenos Aires as heir to the exiles' struggle, both at home and abroad. Sarratea himself had been nominated consul to Valparaíso by the government of Buenos Aires, though his credentials were not accepted by the Chilean government. This was part of a larger struggle between Buenos Aires and Paraná for international recognition, and Chile did in fact recognize Paraná in $1855 .^{62}$ In his letter to Ocampo, however, he was referring not to himself but rather to the recognized representatives of the confederation, the general consul Gregorio Beeche and the former chargé d'affaires Carlos Lamarca, two émigré merchants who had long lived in Valparaíso. Sarratea suggested nominating these two to represent the commission at the exhumation. ${ }^{63}$

Just as the defeat of Buenos Aires's forces at Cepeda had begun a process that would incorporate the city into the nation, it also meant that the dual Argentinean diplomatic representation in Chile had to be reconciled as part of the process of repatriation of Lavalle's remains. It is also here that we get the best sense of how the repatriation commission acted as a quasi-diplomatic body in Chile, representing Buenos Aires in the absence of any diplomatic representation and in a context of conflict and reconciliation between Buenos Aires and the confederation.

The exhumation was seen by Sarratea as an opportunity to bring together Argentina's diplomatic representatives as well as the quarreling members of the émigré community. Lavalle's repatriation promised to heal rifts with roots in the warring constitutional clubs of 1852-1853: Sarratea had been a prominent member of the club loyal to Buenos Aires, whereas Lamarca and Beeche were both central to Alberdi's pro-confederation club. ${ }^{64}$ Reconciling these dueling

61 Mariano Sarratea to repatriation commission, Valparaíso, 21 Nov. 1860, ACAB, CM, AH1617 1. In a previous letter, Ocampo had asked Sarratea to represent the commission at the exhumation, because neither he nor Las Heras was able to travel to Valparaíso to attend. Gabriel Ocampo to Mariano Sarratea, Santiago, 19 Nov. 1860, ACAB, CM, AH1618 1.

62 Barros Arana et al., Cuadro histórico, 253. In a letter to Mitre (at that point Buenos Aires's minister offoreign relations) written shortly after this nomination, Sarratea detailed his diplomatic efforts, which included subsidizing a newspaper published by Domingo Faustino Sarmiento and purchasing educational texts for use in the province's schools. He also had articles favoring Buenos Aires published in El Mercurio, a prominent Chilean newspaper. Mariano Sarratea to Bartolomé Mitre, Santiago, 13 Nov. 1853, in Mitre, Misión, 151-52.

63 Sarratea to commission, Valparaíso, 21 Nov. 1860, ACAB, CM, AH1617 1.

64 The pro-confederation Valparaíso club was a center for distributing pro-Paraná propaganda, including Alberdi's Bases y puntos de partida para la organización política de la República Argentina (1852), throughout America and Europe. Sarratea's efforts should be seen in light of those carried out by Alberdi and his circle in Valparaíso in this same period. 
representatives would ensure a unified diplomacy abroad and unite the émigré community. What is remarkable is that this reconciliation found its expression not in negotiations between Buenos Aires and Paraná but rather in the heart of the émigré communities in Valparaíso and Santiago. This reflects the prominence of exiles in post-Rosas Argentine politics, both in the Rio de la Plata and abroad, and the continuing importance of transnational politics to Argentina almost a decade after Rosas's fall.

Although its original goal was to reinforce Buenos Aires's political legitimacy as a sovereign state, the repatriation commission ended up playing a role in reconciling the exile community around Lavalle's remains. What had begun as an attempt by Buenos Aires to appropriate a potent symbol of the exile struggle had been transformed into an attempt to unify Argentineans abroad. Sarratea was now interpreting Lavalle's repatriation as a symbol of Argentinean unification, an interpretation that would find echoes both within the confederation and in later artworks such as Blanes's aforementioned painting.

Although Sarratea's suggestion to add Lamarca and Beeche to the commission was rejected by Ocampo, who held that the commission's instructions did not allow acceptance of new members, Beeche and Lamarca were invited to participate in the public ceremonies as representatives of the "Argentine Republic." ${ }^{95}$ More important, Sarratea's comments suggest that for the e' migre's themselves repatriation had its own meanings. This is clear in looking at the organization of the ceremonies themselves, first in Valparaíso and then in Santiago. The instructions from Buenos Aires emphasized a ceremony with "all appropriate decorum," and the commission did its best to make the exhumation and repatriation of Lavalle's remains as dignified as possible. ${ }^{66}$ The commission sought to stage a republican funeral through negotiation with Chilean authorities, much as the Potosí commission had tried in Bolivia almost two decades earlier. But whereas the earlier effort at deploying republican imagery aimed to depict an alternative to Rosas in the absence of an Argentine republic, the 1860 effort represented an attempt to consolidate a weak and conflictual legitimacy by presenting a unified republican front abroad.

65 Gabriel Ocampo to Mariano Sarratea, Santiago, 23 Nov. 1860, ACAB, CM, AH1619 1. Ocampo appears to be following Mitre's lead in referring to the "Argentine Republic." One of the changes requested by Buenos Aires before ratifying the 1853 constitution was to replace all references to the country as the "Argentine Confederation" with the "Argentine Nation."

66 “Instrucciones a la comisión,” Buenos Aires, 30 Sept. 1858, in General Lavalle, 7. 
In order to guarantee a ceremony with the dignity of a state funeral, the Chilean authorities' cooperation was necessary. This is where Ocampo's and Las Heras's political integration was key, along with Lavalle's status as a hero of Chilean independence. Sarratea suggested to his colleagues in Santiago that they ask the minister of the interior to "contribute so that those remains receive the honors due to those who fought and spilled blood for the liberty and independence of Chile." ${ }^{97}$ As in Bolivia, the independence struggle provided legitimacy and solidarity. The presence of Las Heras - an independence hero who had fought with both Lavalle and the Chileans — at the head of the commission was highly symbolic.

Both Las Heras and Ocampo used their political contacts in Santiago, including private conversations with the Chilean president, to ensure active participation by the Chilean authorities. ${ }^{68}$ This would include a military escort to honor Lavalle at the exhumation ceremony in Valparaíso, symbolizing continental unity. ${ }^{69}$ After discussing the matter with the intendant, mass was held in the Church of Saint Augustine, chosen for its capacity to fit "the local authorities, soldiers, consular corps, and private individuals" invited by the commission. ${ }^{70}$ Carriages were to be furnished to those who wished to accompany Lavalle's remains to the station, where a special train would carry the body to Santiago. ${ }^{71}$

The participation of the Chilean government would be complemented by that of the diplomatic corps, contributing further to the impression of an official ceremony. It would be presided over by the intendant, in the presence of military officers and the consuls of Brazil, Uruguay, France, and England, all in uniform. ${ }^{72}$ During the procession to the temple, the "precious relics" were "covered with the flag of the patria, and precious allegorical crowns, that some Argentinean ladies [señoras] had draped over it." 73 In this foreign presence and symbolism the procession was similar to the Bolivian funeral as well as the repatriation ceremonies for Bolívar, Gamarra, and

67 Sarratea to commission, Valparaíso, 21 Nov. 1860, ACAB, CM, AH1617 1.

68 Gabriel Ocampo to Mariano Sarratea, Santiago, 23 Nov. 1860, ACAB, CM, AH1619 1; Gabriel Ocampo to Mariano Sarratea, Santiago, 27 Nov. 1860, ACAB, CM, AH1625.

69 Manuel Montt to Gabriel Ocampo, Santiago, 27 Nov. 1860, ACAB, CM, AH1627 1. Montt addressed Ocampo as a "friend."

70 Mariano Sarratea to repatriation commission, Valparaíso, 28 Nov. 1860, ACAB, CM, AH1624 1.

71 Ocampo to Sarratea, Santiago, 27 Nov. 1860, ACAB, CM, AH1625 1.

72 Mariano Sarratea to repatriation commission, Valparaíso, 5 Dec. 1860, ACAB, CM, AC1630 1; Gabriel Ocampo to minister of government of Buenos Aires [likely Dalmacio Ve' lez Sars eld], 8 Dec. 1860, ACAB, CM, AH1629 1.

73 Mariano Sarratea to repatriation commission, Valparaíso, 7 Dec. 1860, ACAB, CM, AH1631 1. 
Rivadavia, to name a few examples.

Sarratea explained that the ceremony was held with all the "solemnity and pomp permitted by our religion" in order to highlight the "Champion of the liberty of the Argentine people [pueblo], the government that requested his remains, and the Chilean people who held him safe for almost 20 years." It was, in his view, a success, "a true celebration and gala for this pueblo" (una verdadera fiesta y gala para este pueblo), who gave Lavalle an "authentic ovation of respect."" Sarratea's comments highlight the public and republican character of the exhumation, which legitimized the newly constituted Argentine Republic, as well as the links between citizens and provinces within Argentina and with neighboring Chile. Lavalle's remains epitomized both the long exile in Chile as well as American unity and the end of exile. At the same time, the comments by Sarratea elide the question of defining the "Argentine people" or the "government" that had requested Lavalle's remains, as can be seen in his use of "pueblo" to refer now to Argentina instead of Buenos Aires.

The speeches given at the exhumation and the ceremony in Valparaíso testify to how exile had connected Chilean and Argentine politics in the previous years. El Mercurio noted that the "Chilean-Argentine fraternity could not have been better represented," quoting the speeches of Argentineans who lauded the Chileans for having welcomed and protected Lavalle's remains for so many years-in terms, not coincidentally, very close to those employed by Sarratea. ${ }^{75}$ Much as Lavalle's original funeral in Bolivia represented a sort of pact with the Bolivian people to shelter Lavalle and the exiles, these comments implicitly thanked the Chileans for protecting the Argentinean e'migre's there during their years in exile.

As at the Bolivian funeral, the speeches at the Valparaíso ceremony were addressed to different publics: the Chileans in attendance, the Argentinean émigrés in Chile, and individuals in the different Argentine provinces who would read about the events and perhaps see the procession on its way to Rosario and Buenos Aires. The speakers included Sarratea and Beeche, representing Buenos Aires and the confederation, as well as Chilean dignitaries. They all focused on consensual themes, such as the exile experience and the independence battles at Chacabuco 74 Ibid. Emotions were running so high that a "young Chilean ... spontaneously" accompanied them to the church. 75 "Los restos del Gnal Lavalle," El Mercurio (Valparaíso), 6 Dec. 1860, in General Lavalle, 30. The speeches appear on General Lavalle, 19-24, and the quotation on ibid., 19. 
and Maipú, where Lavalle, Las Heras, and others had fought to secure Chilean independence. Beeche's comments were typical and suggest the importance of Lavalle's remains to the exile experience: "His bones and heart have been wandering for 20 years now, whether in Bolivia or in Chile, where more than once I have contemplated this sad example of human vicissitudes." ${ }^{76} \mathrm{El}$ Mercurio noted that the temple was decorated "with various American flags belonging to friendly nations, with the Chilean and the Argentinean flags predominating.,"77

The Valparaíso ceremony was also an important opportunity for Argentinean émigrés to manifest their loyalty to the new unified republic. At the exhumation in Valparaíso, a group had "spontaneously" signed an act doing such in the presence of the consul. ${ }^{78}$ Indeed, Sarratea claimed that "a majority of the Argentineans" of Valparaíso was present at the exhumation. ${ }^{79}$ Their public identification shows their intention not only to honor Lavalle - as in the case of those who signed in 1842 — but also to leave a mark of their loyalty to the Argentine Republic and to make their presence at the exhumation known in Chile and Argentina. ${ }^{80}$ The publication in Buenos Aires of the signed Valparaíso act and other documents relating to the exhumation and repatriation publicly reaffirmed the connection that these émigrés felt to the nation, linking the events in Chile and Argentina with a chain of ceremonies and public honors stretching from Valparaíso to Buenos Aires and passing through Santiago de Chile, Mendoza, San Luis, and Rosario.

After the ceremonies in Valparaíso, the procession continued to Santiago, where Las Heras and Ocampo awaited the arrival of Juan Lavalle fils, who had been raised in Chile, with his father's remains. Lavalle entered the Chilean capital on the central boulevard, La Alameda, with Generals Manuel Blanco Encalada and Benjamın Viel, the Uruguayan consul, and "resident Argentineans" before being transferred to the convent of Saint Augustine. Ocampo relayed these details to Buenos Aires, including in his correspondence copies of the documents pertaining to the

76 Ibid., 21.

77 Ibid., 26.

78 Sarratea to commission, Valparaíso, 5 Dec. 1860, ACAB, CM, AC1630 1.

79 Sarratea to commission, Valparaíso, 7 Dec. 1860, ACAB, CM, AH1631

80 The signatures collected seem to indicate that the event attracted many who identified as Argentinean but not with the partisan clubs. Six of the signatories had been members of the constitutional club loyal to Paraná, three of the club loyal to Buenos Aires, and fifteen did not appear on the rolls of either organization (one of whom was Juan Lavalle fils). "Acta de exhumación," in General Lavalle, 15-17. 
exhumation and ceremonies in Valparaíso and Santiago as well as copies of letters to the governments of Mendoza, San Luis, and Rosario. Ocampo indicated that the decision for a land journey, with a final stretch by boat from Rosario, was made by the commission in consultation with Correa de Lavalle and highlighted the participation of the confederation's consul in Valparaíso. $^{81}$

In this sense, Lavalle's repatriation symbolized the connection between émigré and the nation as well as the complicated nature of return from exile. The voyage to Buenos Aires served as a republican pilgrimage from exile to the future capital while passing through an important part of the national territory, unifying the republic as well as the exile community, regardless of their intention to return. All the repatriation commission's members, as well as Beeche and Lamarca, lived out their lives in Chile. Yet they were represented as a part of the new nation. The publication of their names in both Chile and Buenos Aires was important in this recognition of these dual émigré loyalties, making it public knowledge that they still considered themselves Argentinean. In fact, the publication of this affirmation preceded the physical return of Lavalle's remains to Buenos Aires. ${ }^{82}$

\section{Return to the Nation}

In Buenos Aires, a commission was appointed by now-governor Mitre to formally receive the remains and to organize the ceremonies before Lavalle was buried in the Recoleta cemetery. As in Chile, the commission was made up primarily of former exiles, the "most notable people who saved the martyr's ashes in Jujuy." It was directed by Mitre to accompany the body by river from Rosario, where it had arrived by land from Chile. ${ }^{83}$ The scene in Buenos Aires was much like that

81 Gabriel Ocampo to minister ofgovernment, Santiago, 8 Dec. 1860, ACAB, CM, AH1629 1; Gabriel Ocampo to provincial governments, 8-10 Dec. 1860, ACAB, CM, AH1629 1. Blanco Encalada was another independenceera general born in Buenos Aires.

82 For example, the Diario Oficial del Paraná published a letter from Beeche to Emilio de Alvear, minister of foreign relations in the Argentine Confederation, reporting on the commission's progress. Diario O cial del Parana' (Parana'), 30 Nov. 1860, in General Lavalle, 34. The El Mercurio articles and accompanying speeches, previously cited, were reprinted in "Los restos del General Lavalle," El Nacional (Buenos Aires), 2 Jan. 1861, pp. 1-2.

83 Juan Esteban Pedernera, who had led the retreat to Bolivia with Lavalle's remains, was named president. Decree, Buenos Aires, 31 Dec. 1860, in General Lavalle, 37. The decree was signed by Mitre, Sarmiento, Rufino de Elizalde, and Juan Andre's Gelly y Obes, all members of Mitre's cabinet. All except Elizalde were former émigrés. The commission also included Félix Frias and Alejandro Danel. 
in Potos1, Valparaíso, and Santiago. There were military honors, cannons fired, an orchestra and choir, and the flags of South American countries. The speeches were published in El Nacional. ${ }^{84}$ The speeches and accompanying press coverage show how Lavalle's memory was shaped by political conflict over the recent past. Mitre's speech highlights the way that exile and the return of Lavalle's remains were understood by the post-Rosas political elite of Buenos Aires: “These are the mortal remains of General Juan Lavalle, returned to their native soil after 20 years of proscription in the tomb; and this is the pueblo of Buenos Aires that triumphantly carries them to their eternal resting place, after having received honors from Bolivia, Chile, and the Argentine Republic!" 85 According to Mitre here, the exile experience was key to understanding the pastand a affirming power in the present-in Buenos Aires, even as the porteño experience was assimilated to that of the nation. Mitre also noted that the remains would "lie next to those of Rivadavia that were also proscribed like those of Lavalle." 86 A pantheon of republican exile helped legitimize the unification of the republic, connecting national organization to their return.

Lacasa made an even more explicit reference to the regional context ofexile and repatriation by mentioning the death in exile of independence leaders such as Bolıvar, Antonio José de Sucre, and the Chilean Carrera brothers, among others: "Lavalle, dead 500 leagues from his country, is saved on the shoulders of his comrades in misfortune and carried to the land of exile; and 20 years later his ashes, blessed by all, return home to mix with those of Belgrano, Rivadavia, Varela; while those of Rosas . . . as one of our first bards prophetically said, will not be buried in American soil.." ${ }^{87}$ Again the confusion between Buenos Aires and the nation, again exile and independence figure prominently in his speech, as does Rosas. Lavalle's role in the civil wars does not.

This association of the exile experience with Buenos Aires city was not unanimous. La Reforma Pacufica published a series of articles critical of the ceremonies. While holding on to the

84 “Documentos oficiales," El Nacional (Buenos Aires), 22 Jan. 1861, p. 1; "Discursos," El Nacional (Buenos Aires), 22 Jan. 1861, p. 2; Juan Marıa Gutiérrez, “Lavalle!!,” El Nacional (Buenos Aires), 19 Jan. 1861, p. 1. They were reprinted with additional speeches in General Lavalle, 48-83.

85 "Discurso del Sr. Gobernador Mitre," in General Lavalle, 62.

86 Ibid., 63.

87 "Discurso pronunciado al llegar al estremo del muelle el cortejo fúnebre del General Lavalle," in Lacasa, Poesias, 253-54. Indeed, Rosas's remains would not be repatriated until 1989, which refocused attention on some of these same debates as well as themes of reconciliation and return. Shumway, "Sometimes Knowing." " 
importance of Lavalle as a figure of independence as well as of exile and anti-Rosismo, the newspaper claimed that many of those clamoring to accompany Lavalle's remains to Buenos Aires had not, in fact, accompanied his body to Bolivia. ${ }^{88}$ This appears to be a criticism of those who had previously accommodated themselves to the Rosas regime and were now allying with Buenos Aires against the confederation. The editors also reminded the public of Lavalle's role in the execution of Dorrego in $1828 .{ }^{89}$

While Buenos Aires's interests predominated in the ceremonies, they were not the only ones present. Juan Marıa Gutiérrez, most notably, made a speech that pointed out how Lavalle's "ashes [had] remained in exile" for eight years after the fall of Rosas. ${ }^{90}$ Gutiérrez, a porteño supporter of the Paraná government, was undoubtedly referring to the divisions between Buenos Aires and the confederation that had not only kept Lavalle's remains from returning but had also prevented the unification of Argentina for which the exiles had suffered. Their return implied hope for the unification of the nation. ${ }^{91}$

The consensual tropes of independence, republicanism, and exile central in many of the speeches, including those by Mitre, Lacasa, and Gutiérrez, were also linked to Buenos Aires's own particular experience, as opposed to a broader Argentinean one. This shows the limits of evoking exile to legitimize the hold of Mitre and his allies on power. Not only was Lavalle a problematic symbol of unity, but many of the confederation's leading figures had also spent time in exile in opposition to Rosas, and not a few were porteños or former Unitarians.

The expressions of unity found in Chile and Argentina during the repatriation of Lavalle's

88 "El general Lavalle y los farsantes," La Reforma Pacıfica (Buenos Aires), 4 Jan. 1861.

89 "Las exequias del jeneral Lavalle," La Reforma Pacıfica (Buenos Aires), 6 Jan. 1861. After criticism from other newspapers, La Reforma Pacifica explained its position following the ceremonies on January 19, 1861, by noting that there were three different Lavalles: the one who had fought in the wars of independence (and who should be honored), another who had ordered the "criminal" execution of Dorrego, and a third whose fight against Rosas had been largely "sterile," due to his military failures in 1840. This effectively encapsulates the controversies surrounding Lavalle’s memory. "El general Lavalle,” La Reforma Pacifica (Buenos Aires), 20 Jan. 1861.

90 General Lavalle, 75.

91 It should also be noted that Pedernera, named by Mitre to preside over the Buenos Aires commission, declined to participate, ostensibly because of his health. Juan Esteban Pedernera to Bartolomé Mitre, Paraná, 14 Jan. 1861, in General Lavalle, 46-47. The nomination of Pedernera, vice president of the confederation in 1861 (and its last president, after the Battle of Pavón), could be seen as a conciliatory measure, framing the repatriation in terms of unity and the integration of Buenos Aires into the nation. On the other hand, his resignation was apparently seen as a criticism of the political use of the repatriation. La Reforma Pacıfica (Buenos Aires), 17 Jan. 1861, claimed that Pedernera did not wish to "insult" Lavalle's remains by participating in the legitimation of Mitre's position. 
remains covered over the persistence of deeper divisions between Buenos Aires and the other provinces, hinted at in these criticisms of the Buenos Aires ceremonies. These divisions led to another outbreak of war, at Pavón in September 1861. This time Mitre's forces were victorious, allowing him to consolidate his political position, and he was elected president of a united republic in August 1862. The political uses of Lavalle's remains provide insight into the important role played by exile and transnational politics in the conflict between Buenos Aires and the confederation and in the constitution of a united Argentine Republic.

\section{Exile, Dual Loyalty, and Republican State Formation}

In Chile, en route through the confederation, and in Buenos Aires, Lavalle's remains - and the exile experience itself-were subject to differing interpretations. For émigrés still residing in Chile, the exhumation and repatriation were an opportunity to publicly voice their loyalty to the new republic being formed in the R10 de la Plata and to participate in political debate. For the Buenos Aires leadership, many of whom were exiles themselves and were connected to these émigrés through shared experiences in Chile, the return of Lavalle's remains from exile validated their hold on power and their claim to represent the Argentine nation in the conflict with the confederation, through a continuous line of republican exiles going back to independence. Although this vision was contested by former comrades in exile such as Gutiérrez, who supported the confederation, it highlights how exile and return were important in the legitimation of the republic's political elite as well as the transnational politics behind nation-state formation in Argentina.

The Buenos Aires leadership recast Lavalle as a unifying figure for the anti-Rosas exiles, drawing on his role in the independence wars and the 1839-1841 campaign along with his martyrdom. This was only partially successful given Lavalle's role in some of the most contentious episodes of the civil wars, in particular the execution of Dorrego, which unleashed a spiral of violence that left scars for decades. But even those critical of the repatriation ceremonies and their use of Lavalle's memory shared the historical representation of the exile experience as well as a certain complicated regard for Lavalle as an independence hero and antiRosas émigré. The exile experience, in Buenos Aires and Paraná, was associated with the 
formative moments in the constitution of the republic, a badge of struggle and political authenticity. This association should not be surprising given the twists and turns of political alliances, but it also underscores the importance of exile and return to political elites in the nineteenth century. The reason that Lavalle's memory could speak to those on both sides of the Buenos Aires-confederation divide was this shared experience.

In the face of persistent political divisions, exile was an experience shared by leaders in Paraná and Buenos Aires that could be mobilized for unity - or to legitimize divisions. The memory of exile endured not only within republican Argentina but also in the communities that remained abroad. Not all émigrés return to their country of origin, and the question of dual loyalties, nonexclusive nationality, and transnational politics in transitional regimes has received little attention for the nineteenth century. The political integration of exiles in Chile was seen by the Buenos Aires government not as conflictual but as an asset in its dispute with the confederation that could be used to further foreign policy goals, in an early form of transnational political mobilization that predated the nation and played a role in its organization.

For its members, the repatriation commission provided the opportunity to reinforce their ties to Buenos Aires, either by envisaging the possibility of return or-more likely, perhaps - further solidifying their position in the Argentine émigré community and with the Chilean government. At the same time, the repatriation ceremony in Valparaíso was an important event for the Argentine émigrés of Chile, provoking public displays of emotion that were repeated in Argentina both in the press and in the repatriation pilgrimage. This complicates notions of return, in particular for someone like Ocampo, whose political life straddled both countries even 50 years after independence. Argentineans outside the confederation's borders were determined to maintain a voice in the constitutional process at the foundation of the republic.

Lavalle's body thus symbolized not only the unification of Argentina (and the prominence of Buenos Aires manifested in Mitre's representations of Lavalle's memory) but also the symbolic return of exiles to the nation. These exiles included Lavalle himself, those who accompanied his body to Bolivia (Frías and Pedernera), the first two presidents of the united republic (Mitre and Sarmiento), and important intellectual figures (such as Alberdi and Gutiérrez). This suggests the important role that exile and return played in national organization, a role that has yet to be fully 
elucidated. In their return to the capital, Lavelle's remains symbolized the exile struggle against Rosas that legitimized new rulers in Buenos Aires as well as Paraná. The return of Lavalle's son represented the new generation, born in exile, that would one day take the reins of power. Exile affirmed not only Buenos Aires's dominance, around the figures of Mitre and Lavalle, but also to a lesser extent the confederation's elites and the unified nation more generally. The memory of exile, as an experience unifying political elites across different provinces and republics, provided a way to attempt to resolve the confusion between the pueblo of Buenos Aires and the Argentine Republic; this is what Blanes represented pictorially through the body of Lavalle, draped in an Argentine flag and being carried into Bolivia. The relationship between political violence, the symbolism of the body, and exile and return was key to the foundation of the Argentine Republic. As Ernesto Sabato suggests, however, exile and the political power of the body in death were to remain central to Argentinean political practice.

\section{References}

Adelman, Jeremy. 1999. Republic of Capital: Buenos Aires and the Legal Transformation of the Atlantic World. Stanford, CA: Stanford University Press.

Adelman, Jeremy. 2010. "The Rites of Statehood: Violence and Sovereignty in Spanish America, 1789-1821." Hispanic American Historical Review 90, no. 3: 391-422.

Alberdi, J. B. 1900. Memorias y documentos. Vol. 15 of Escritos póstumos. Buenos Aires: Imprenta Juan Bautista Alberdi.

Barros Arana, Diego, Marcial González, José Victorino Lastarria, and Domingo Santa Marı, eds. 1861. Cuadro histórico de la administración Montt, escrito según sus proprios documentos. Valparaíso: Imprenta i Libreria del Mercurio de Santos Tornero.

Bragoni, Beatriz. 1996. "La utopıa constitucionalista: Alberdi y el club argentino de Valparaíso." Revista de Historia de América, no. 121: 27-43.

Caretta, Gabriela, and Isabel Zacca. 2011. "Itinerarios de un cuerpo: Los segundos funerales de Güemes en el proceso de construcción de memorias." In Travesia discursiva: Representaciones 
identitarias en Salta (siglos XVIII-XXI), edited by Sara Mata and Zulma Palermo, 71-91. Rosario: Prohistoria Ediciones.

Danel, Alejandro. 1888. “Auto-biografia.” Revista Nacional (Buenos Aires), no. 5: 46-64.

Fradkin, Raúl. 2012. ¡Fusilaron a Dorrego! Buenos Aires: Editorial Sudamericana.

Gallo, Klaus. 2006. The Struggle for an Enlightened Republic: Buenos Aires and Rivadavia.London: Institute for the Study of the Americas.

Gallo, Klaus, and Manuel Socias. 2006. "La repatriación del 'padre de Buenos Aires': Bernardino Rivadavia y la refundación de la república liberal en Argentina.” In McEvoy 2006b, 81-99.

Gelman, Jorge. 2009. Rosas bajo fuego: Los franceses, Lavalle y la rebelión de los estancieros. Buenos Aires: Editorial Sudamericana.

General Lavalle: Documentos relativos a la traslación de los restos mortales y exequias funebres del general D. Juan Lavalle. 1861. Buenos Aires: Imprenta del Comercio del Plata.

González Bernaldo de Quirós, Pilar, Civilité et politique aux origines de la nation argentine: Les sociabilités à Buenos Aires 1823-1862 (Publications de la Sorbonne, 1999)

Halperın Donghi, Tulio. 1980. "Una nación para el desierto argentino." In Proyecto y construcción de una nación (Argentina 1846-1880), xi-ci. Buenos Aires: Biblioteca Ayacucho.

Iriarte, Tomás de. 1948. Memorias. Vol. 6, La tiranía de Rosas y el bloqueo francés. BuenosAires: Ediciones Argentinas "SIA."

Johnson, Lyman L., ed. 2004. Death, Dismemberment, and Memory: Body Politics in Latin America. Albuquerque: University of New Mexico Press.

Katra, William H. 1996. The Argentine Generation of 1837: Echeverria, Alberdi, Sarmiento, Mitre. Madison, NJ: Fairleigh Dickinson University Press.

Lacasa, Pedro. 1842. Campaña del primer ejército libertador de la República Arjentina, al mando del jeneral D. Juan Lavalle contra el tirano de los pueblos del Plata. Valparaíso: M. 
Rivadeneyra.

Lacasa, Pedro. 1858. Vida militar y polttica del general argentino don Juan Lavalle. Buenos Aires: Imprenta Americana.

Lacasa, Pedro. 1870. Poesias y escritos del coronel don Pedro Lacasa. Buenos Aires: Imprenta de la Discusión.

la Madrid, Gregorio Aráoz de. 1895. Memorias del general Gregorio Aráoz de la Madrid. Vol. 1. Buenos Aires: Establecimiento de Impresiones de Guillermo Craft.

McEvoy, Carmen. 2006a. “El regreso del héroe: Bernardo O’Higgins y su contribución en la construcción del imaginario nacional chileno, 1868-1869.” In McEvoy 2006b, 125-82.

McEvoy, Carmen, ed. 2006b. Funerales republicanos en América del sur: Tradición, ritual y nación, 1832-1896. Santiago: Ediciones Centro de Estudios Bicentenario.

Mitre, Bartolomé. 1912. Misión del general D. José M. Paz. Vol. 14 of Archivo del general Mitre. Buenos Aires: Biblioteca de "La Nación."

Myers, Jorge. 1998. "La revolución en las ideas: La generación romántica de 1837 en la cultura y en la política argentinas." In Nueva historia Argentina, vol. 3, Revolución, república, confederación (1806-1852), edited by Noem1 Goldman, 383-445. Buenos Aires: Editorial Sudamericana.

Pasquali, Patricia. 1996. Juan Lavalle: Un guerrero en tiempos de revolución y dictadura. Buenos Aires: Planeta.

Paz, José María. 1855. Memorias póstumas del brigadier general D. José M. Paz.... Vol. 2. Buenos Aires: Imprenta de la Revista.

Podgorny, Irina. 2010. "Las momias de la patria: Entre el culto laico, la historia de la química y la higiene pública.” L’Ordinaire des Amériques 212: 53-74.

Prado O., Juan Guillermo. 2010. "Reflexiones en torno a la nacionalidad chilena de Andrés Bello." Revista Chilena de Historia y Geografia, no. 170: 219-30. 
Rabinovich, Alejandro Martin. 2013. La société guerrière: Pratiques, discours et valeurs militaires dans le Rio de la Plata, 1806-1852. Rennes, France: Presses Universitaires de Rennes. Rodríguez, María Inés, and Miguel José Ruffo. 2002. "Paisaje y tragedia en Nicanor Blanes: La conducción del cadáver de Lavalle en la Quebrada de Humahuaca." Jornadas: Estudios e Investigaciones 5: 281-90.

Rojas, Rafael. 2009. Las repúblicas de aire: Utopıa y desencanto en la revolución de Hispanoamérica. Mexico City: Taurus.

Sabato, Ernesto. (1961) 2004. Sobre héroes y tumbas. Caracas: Biblioteca Ayacucho.

Sarmiento, Domingo Faustino. 1874. Facundo: Ó, civilización i barbarie en las pampas argentinas. Paris: Librerı Hachette.

Sarmiento, Domingo Faustino. 1897. Las ciento y una (época pre-constitucional). Edited by A. Belin Sarmiento. Vol. 15 of Obras de D. F. Sarmiento. Buenos Aires: Imprenta y Litografia "Mariano Moreno."

Sarmiento, Domingo Faustino. 1900. Páginas literarias. Edited by A. Belin Sarmiento. Vol. 46 of Obras de D. F. Sarmiento. Buenos Aires: Imprenta y Litografia "Mariano Moreno."

Scobie, James R. 1964. La lucha por la consolidación de la nacionalidad argentina, 18521862. Buenos Aires: Libreria Hachette.

Shumway, Jeffrey M. 2004. “ 'Sometimes Knowing How to Forget Is Also Having Memory': The Repatriation of Juan Manuel de Rosas and the Healing of Argentina.” In Johnson 2004, 10540.

Sobrevilla Perea, Natalia. 2006. "La repatriación del generalısimo Agustín Gamarra y la construcción del imaginario nacional en Peru', 1848." In McEvoy 2006b, 57-80.

Sobrevilla Perea, Natalia. 2011. The Caudillo of the Andes: Andrés de Santa Cruz. New York: Cambridge University Press.

Sznajder, Mario, and Luis Roniger. 2009. The Politics of Exile in Latin America. New York: 
Cambridge University Press.

Zubizarreta, Ignacio. 2014. Unitarios: Historia de la facción polttica que diseñó la Argentina moderna. Buenos Aires: Sudamericana.

Edward Blumenthal is Assistant Professor of Latin American studies at the Université Sorbonne Nouvelle (Paris 3-USPC). He is currently completing a book manuscript, tentatively titled "Exile and Nation-State Formation in Nineteenth-Century South America," and is starting a new project on the relationship between exile and the codification of international law in Latin America in the nineteenth and twentieth centuries. 